\title{
Several melanosis-inhibiting formulas to enhance the quality of deepwater pink shrimp (Parapenaeus longirostris)
}

\author{
M.E. López-Caballero*, O. Martínez-Álvarez, M.C. Gómez-Guillén, P. Montero
}

Institute of Food Science, Technology and Nutrition, ICTAN-CSIC. C/ José Antonio Novais 10, 28040 Madrid (Spain). Tel.: +34 91 5445607; Fax: +34 915493627

*Author for correspondence: elvira.lopez@ictan.csic.es

\begin{abstract}
The aim of this work was to assess the effect of several melanosis-inhibiting formulations on quality of deepwater pink shrimp (Parapenaeus longirostris) during storage. The formulations tested were as follows: one containing 4-hexylresorcinol $(0.1 \%)$ in combination with organic acids (citric, ascorbic and acetic) and chelating agents (ethylenediaminetetraacetic acid [EDTA] and di-sodium di-hydrogen pyrophosphate [PPi]); a commercial formula based on sulphites (3\%), and another formulation containing a mixture of chitosan $(0.3 \%)$ and commercial sulphites. Nontreated shrimp were used as control. The 4-hexylresorcinol-based formulation was more effective than $3 \%$ of commercial sulphite solutions in preventing melanosis. This treatment prolonged the sensory acceptability of shrimp by up to six days in ice storage. During chilled storage, the treatment with the 4-hexylresorcinol-based formula inhibited the growth of microorganisms by 1.5-2 log cycles as compared to commercial sulphites, especially $\mathrm{H}_{2} \mathrm{~S}$-producers and pseudomonads. At the end of the experimental period, TVB-N levels were slightly higher in the lot treated with 4-hexylresorcinol (33 mg/100 $\mathrm{mg}$ ) and reflected greater endogenous enzymatic activity, since the counts of the spoiler microorganisms remained around $\log 5 \mathrm{cfu} / \mathrm{g}$ or even lower. In general, the incorporation of chitosan to sulphites did not improve or produce a marked effect on shrimps during storage. During the sensory analysis, the panellists rated all the lots very similar, although the 4-hexylresorcinol formulation was the only one with a neutral odour at the end of the period. The 4-hexylresorcinol-based formulation induced yellow-green colorations to some extent in the cephalothorax, possibly due to the effect of organic acids and chelants, while the rest of the lots presented greyish/blackish colorations. Therefore, the formulation based on 4-hexylresorcinol may safely substitute
\end{abstract}


traditional sulphites to improve the quality of fresh shrimp and prolong their shelf life during storage.

Key words: shrimp, melanosis, 4-hexylresorcinol, sensory analyses, shelf-life 


\section{INTRODUCTION}

In Europe, the average seafood per capita consumption is about $25.8 \mathrm{~kg}$ (EUMOFA, 2017). In Spain, the seafood consumption is around $24.87 \mathrm{~kg} / \mathrm{inh}$ abitant, of which 1.2 $\mathrm{kg}$ were shrimps and lobsters (Statista, 2018). Deepwater pink shrimp (Parapenaeus longirostris) is, together with Norway lobster, one of the products most consumed, with an upward trend both in production and prices worldwide. Deepwater pink shrimp is also of great economic importance to Mediterranean countries, but although it is highly acceptable and economically valuable, this crustacean specie is very perishable. Spoilage begins immediately after death with the appearance of melanosis, which in many cases, especially if the temperature reduction is not carefully controlled, is quickly accompanied by the production of volatile compounds and microbial proliferation. Both melanosis and microbial spoilage strongly reduces the marketability of deepwater pink shrimp, and makes necessary the search for additives and/or technologies to avoid or delay the loss in its market value.

Sulphites are very effective in preventing melanosis, although their impact on health, chiefly in respiratory processes, has been known for decades (McEvily et al., 1991), and hence the importance of investigating other options. In addition, sulphites are present in many other foods (Timbo et al., 2004), for instance as antimicrobials in the wine industry, etc., which increases the exposure of consumers to these compounds. In fact, the European Commission has considered some alternatives to sodium metabisulphite and/or reviewed the specific conditions for their use (EGTOP, 2014). Moreover, the Directive of the European Parliament and of the Council (amendment of Directive 95/2/EC) proposes the polyphenol 4-hexylresorcinol as an alternative to sulphites to prevent the appearance of melanosis in crustaceans during storage. Therefore, in recent years, research has focused on looking for alternative compounds and/or coadjutants to the traditional sulphites so as to substitute or reduce the dose used and thus prevent the appearance of black spots, and/or prolong shelf-life. Several 4-hexylresorcinol-based formulae have been used with promising results to prevent the appearance of black spots in Norway lobster (López-Caballero et al., 2006a; Martínez-Álvarez et al., 2007), in frozen and/or cooked prawn (López-Caballero et al., 2007; Martínez-Álvarez et al., 2009) and in raw tiger prawns (Martínez-Álvarez et al., 2005b; Montero et al., 2001) during chilled storage. Among its multiple applications (biomedical, wastewater treatment, agriculture, food protection, cosmetic, etc., Muxika et al., 2017), chitosan has been used to prevent melanosis, in a solution (Simpson et al., 1997), as a coating alone 
(Arancibia et al., 2015) or as a coating in combination with pomegranate peel extract (Yuan et al., 2016a), carvacrol and/or caprylic acid (Wang et al., 2018) or green tea (Yuan et al., 2016b), or even as a film combined with orange peel essential oil (Alparslan and Baygar, 2017). These formulae including chitosan or 4-hexylresorcinol could also be useful to delay microbial spoilage of deepwater pink shrimp during chilled storage. However, to the best of our knowledge, this effect has been hardly studied in crustaceans. As well, there is no information on the use of such compounds to preserve the quality of deepwater pink shrimp during chilled storage. This is of particular interest since the onset of melanosis and microbial spoilage are specific to each crustacean species and dependent on its physiology.

The objective of this work was therefore to assess the effect of several melanosisinhibiting formulae including 4-hexylresorcinol or chitosan on the sensorial and microbial quality of deepwater pink shrimp during chilled storage. A commercial sulphite-based formula was also evaluated for control purposes.

\section{MATERIAL AND METHODS}

\section{Sample preparation}

Deepwater pink shrimp (Parapenaeus longirostris) were caught off the South coast of Spain (Gulf of Cádiz) by trawl in November. On board they were separated from the bycatch, and washed with seawater. The shrimp were separated in 4 batches, one of these was considered as control with no additives (AF). A commercial sulphite based product (Hasenosa S.A., Vigo, Spain) at 4\% (expressed as g compound per $100 \mathrm{~g}$ shrimps) was applied by immersion (shrimp:seawater:ice relation of 1:2:1), alone (lot $S$ ) and accompanied with $0.3 \%$ (w/w, g product per $100 \mathrm{~g}$ prawn) of chitosan previously diluted in $0.05 \mathrm{M}$ acetic acid (v/v), (lot S-Ch). The commercial sulphite based product included sodium metabisulphite (60\% maximum content), citric acid, ascorbic acid, EDTA and sodium bicarbonate in the formulation. The melanosis-inhibiting blends were dissolved in seawater and afterwards the shrimp were immersed and covered with ice for 1 hour. Moreover, another batch was treated with $0.1 \%$ (g of inhibitor per $100 \mathrm{~g}$ of shrimp) 4-hexylresorcinol (Sigma, St. Louis, MO, USA) in combination with reagent grade citric acid $(0.5 \%)$, ascorbic acid $(0.5 \%)$, acetic acid $(0.05 \mathrm{~N})$, ethylene diamine tetra-acetic acid (EDTA) [450 ppm], and disodium dihydrogen pyrophosphate (PPi) [1.5 $\%$ ] (lot HR). The organic acids were included in this formulation in order to decrease 
$\mathrm{pH}$ and/or to avoid (or delay) oxidation of phenols to quinones. EDTA and PPi were included with the aim to inhibit the activity of endogenous proteases that could convert proPPO or hemocyanin into PPO-like molecules. These chemicals were diluted in approximately 1 litre of seawater and sprayed on the surface of the crustaceans. Once finished the treatment time, the shrimp were taken away, placed in perforated polystyrene boxes of $2 \mathrm{~kg}$ of capacity, and covered with ice. Subsequently, shrimps were placed in perforated polystyrene boxes of $2 \mathrm{~kg}$ of capacity, and covered with ice. On arrival of the trawler in port, the boxes were taken by refrigerated truck to ICTAN, Madrid (Spain), where they were stored at low temperature (2 C). Further analyses were performed during the storage.

\section{Polyphenoloxidase (PPO) activity determination}

The crude enzyme was obtained from cephalothorax carapaces. They were separated from the viscera on sampling days during chilled storage, frozen and stored at $-80{ }^{\circ} \mathrm{C}$ until analysis. Crude extracts were obtained according to Wang et al. (1992), with slight modifications (Martínez-Álvarez et al., 2007).

The enzyme activity was measured using the proline-catechol spectrophotometric assay (Rzepecki \& Waite, 1989) at saturating conditions, according to Wang et al. (1992). The results were expressed as Units/mL of crude enzyme, considering the unity as an increment of 0.01 absorbance/min. Analyses were performed in triplicate.

\section{Colour}

Lightness $\left(\mathrm{L}^{*}\right)$, yellowness $\left(\mathrm{b}^{*}\right)$, and redness $\left(\mathrm{a}^{*}\right)$ of dried and well-pulverized cephalothorax carapace were measured with a Hunterlab colorimeter (Hunter Associates Laboratory, Inc., Reston, Virginia, USA), using a CIELab scale (Young \& Whittle, 1985). With $L^{*}, a^{*}$ and $b^{*}$ values, whiteness (W) was calculated, according with Park (1994). Results were expressed as the mean of six measurements.

\section{pH}

Approximately 5-10 grams of muscle was homogenized with a double quantity $(\mathrm{g} / \mathrm{ml})$ of distilled water. After five minutes at ambient temperature, $\mathrm{pH}$ was determined with a pHm93 pH-meter and a combined pH electrode (Radiometer, Copenhagen, Denmark). The experiments were repeated at least in triplicate. 


\section{Water holding capacity (WHC)}

WHC was determined by the method described by Montero et al. (1996). Two grams of muscle were chopped, weighed and placed in a centrifuge tube, with three pipette filters (Gilson Pipetman, France) as absorbents. Samples were centrifuged for $10 \mathrm{~min}$ at 6000 $\mathrm{x} \mathrm{g}$ in a Sorvall RT60008 centrifuge (DuPont Co., Delaware, USA) at room temperature. Results were average of 3 determinations and were expressed as $\mathrm{g}$ of water/ $g$ of protein in muscle.

\section{Total volatile basic nitrogen (TVB-N)}

Total volatile basic nitrogen (TVB-N) determinations were carried out in triplicate over the storage period using the method of Antonacopoulos \& Vyncke (1989). Thus, $10 \pm$ $0.1 \mathrm{~g}$ of the ground sample were weighed in a suitable container and homogenized for two minutes with $100 \mathrm{ml}$ of $6 \%$ perchloric acid solution. After filtered, the extract was alkalinized with $20 \%$ sodium hydroxide solution and submitted to steam distillation. The volatile base components were absorbed by an acid receiver and determined by titration of the absorbed bases. All analyses were performed at least in triplicate.

\section{Biogenic amines}

Agmatine (Agm), Cadaverine (Cad), Histamine (His), Putrescine (Put) and Tyramine (Tyr) was performed in a $10 \%$ trichloroacetic acid extracts $(1: 2 \mathrm{w} / \mathrm{v})$ by HPLC on a reverse-phase column (Spheri-5RP18, Brownlee, Labs., CA, USA), followed by postcolumn derivatisation with o-phthalaldehyde, as described by Ritchie (1991). Results of three replicates were expressed as $\mu \mathrm{g}$ of amine per millilitre $(\mu \mathrm{g} / \mathrm{ml})$ of wet sample.

\section{Microbiological analyses}

A total amount of $10 \mathrm{~g}$ of muscle was collected under aseptic conditions and transferred into sterile bags (Sterilin, Stone, Staffordshire, UK), combined with $90 \mathrm{ml}$ of buffered $0.1 \%$ peptone water (Oxoid, Basingstoke, UK) and shaken vigorously for $1 \mathrm{~min}$ in a Stomacher blender (model Colworth 400, Seward, London, UK). Then, appropriate dilutions were prepared for the following microorganism determinations: (i) total bacterial counts (TBC) on spread plates of Iron Agar (Scharlab, Barcelona, Spain) 1\% $\mathrm{NaCl}$, incubated at $15^{\circ} \mathrm{C}$ for 3 days; (ii) $\mathrm{H}_{2} \mathrm{~S}$-producers organisms, as black colonies, on spread plates of Iron Agar incubated at $15{ }^{\circ} \mathrm{C}$ for 3 days; (iii) luminescent bacteria on spread plates of Iron Agar $1 \% \mathrm{NaCl}$ incubated at $15^{\circ} \mathrm{C}$ for 5 days; (iv) Pseudomonas on 
spread plates of Pseudomonas Agar Base (Oxoid) with added CFC (Cetrimide, Fucidine, Cephalosporine) supplement for Pseudomonas spp. (Oxoid) incubated at 25 ${ }^{\circ} \mathrm{C}$ for $48 \mathrm{~h}$; (v) Enterobacteriaceae on double-layered plates of Violet Red Bile Glucose Agar (VRBG, Oxoid) incubated at $30{ }^{\circ} \mathrm{C}$ for $48 \mathrm{~h}$; and (vii) lactic acid bacteria on double-layered plates of MRS Agar (Oxoid) incubated at $30^{\circ} \mathrm{C}$ for $72 \mathrm{~h}$. Culture was under aerobic conditions for the mentioned microorganisms. All analyses were performed at $0,3,5,7,10$ and 14 days by duplicate. The day when the shrimp were coated was taken as day 0. Microbiological counts were expressed as the log of the colony-forming units per gram (log CFU/g) of sample.

\section{Sensory evaluation}

Over the 10-day storage period a group of trained panellists routinely evaluated shrimp appearance every two-three days (10 individuals per treatment per evaluation). Melanosis was scored according to a scale of from 1 to 4 where $1=$ complete absence of black spots; $2=$ a few small spots on the carapace; $3=$ considerable spotting on the carapace; 4= substantial spotting over the entire shrimp. The presence of yellowgreenish colouration beneath the head cuticle was scored according to a scale from 5 to 0, where 5=typical pink colour: 4-3=yellow pale/yellow colouration; 2-1= green pale/green colouration and $0=$ dark. The tight junction between abdomen and cephalothorax was scored as 5 (tight) to 0 (loose). Odour was evaluated according to a scale from 0 to where $5=$ sea; $4=$ typical; $3=$ neutral; $1=$ slightly ammonia; $2=$ ammonia; $0=$ off-odour.

\section{Statistical analyses}

The significance of differences between mean values was evaluated using two-way ANOVA. Statistical processing was by the SPSS 12.0 computer program (Chicago, Illinois, USA). The level of significance setting was $\mathrm{p} \leq 0.05$.

\section{RESULTS AND DISCUSSION}

The initial $\mathrm{pH}$ of the shrimp was 7.2, similar to that found in a previous work with the same species (López-Caballero et al., 2007). This figure was not significantly changed by the effect of the treatment (data not shown). The level increased by approximately one unit after 6 days due to the accumulation of microbial metabolites and endogenous 
enzymatic action, reaching values of up to 8 . There were no significant treatmentinduced differences between batches $(\mathrm{p} \leq 0.05)$.

From the beginning to the end of the storage, the various treatments with melanosisinhibiting agents did not significantly alter the muscle protein, with water holding capacity evolving similarly in all batches and decreasing slightly over storage (data not shown). Initial WHC was around $80 \%$, dropping to around $77 \%$ at the end of the storage period.

The post-catch concentration of TVB-N in shrimp was $29.3 \mathrm{mg}$ N/100 $\mathrm{g}$ of muscle. Fresh crustaceans with these values have been considered of good quality (Mendes et al., 2002). After the treatments, TVB-N decreased in all lots $(\mathrm{p} \leq 0.05)$, which was attributed to the release of basic compounds to the aqueous media, since the treatments were applied in solution (Table 1). Thereafter, TVB-N, largely in the form of ammonia (López-Caballero et al., 2006a) increased until 6 d. After that, TVB-N levels declined. The same pattern was reported by Martínez-Álvarez et al. (2005b) in cultured prawns and was possibly due to washing by melting ice. At the end of storage, lot HR registered $33 \mathrm{mg} / 100 \mathrm{~g}$ muscle $(\mathrm{p} \leq 0.05)$ probably due to autolytic processes since the microbial counts were higher in the control lot, as will be discussed below In this regard, the autolysis of cephalothorax seemed to be slightly higher in shrimp treated with the HR formula, thereby releasing active proteases into the muscle that could be responsible for the higher amount of TVB-N observed in this lot. Galvão et al., (2017) obtained that shrimp (Xiphopenaeus kroyeri) treated with $0.01 \%$ or $0.1 \%$ of 4 -hexylresorcinol did not exceed $30 \mathrm{mg} / 100 \mathrm{~g}$ during the 12 days of storage, while the discard of the cephalothorax in these shrimps allowed to maintain the state of freshness for 10-12 days.

The biogenic amines in crustaceans perform different functions, such as serving as neuromodulars or neurohormones (Fingerman et al., 1994) and they are produced as a result of decarboxylase activity of endogenous and microbial enzymes on amino acids (Silla Santos, 1996). In the present work, initially the biogenic amines were below the limit of detection (tyramine $<4.15 \mu \mathrm{g} / \mathrm{ml}$, putrescine $<1.93 \mu \mathrm{g} / \mathrm{ml}$, cadaverine $<0.35$ $\mu \mathrm{g} / \mathrm{ml}$, histamine $<3.26 \mu \mathrm{g} / \mathrm{ml}$ ) irrespective of the treatment (data not shown). LópezCaballero et al. (2002a) reported that agmatine concentrations were the highest during 
the storage of iced shrimp, since amino acid arginine is found in high concentrations in crustaceans (Huidobro et al., 2002). However, the present authors observed no such behaviour, with all batches registering agmatine concentrations $<0.53 \mu \mathrm{g} / \mathrm{ml}$ regardless of treatment. During chilled storage of Norway lobster, the production of agmatine and putrescine (ranging from ca. 26 to $9 \mathrm{mg} / \mathrm{kg}$ respectively) was higher in lobster treated with formulations based on 4-HR than with commercial sulphites, and was related to the microbiota (i.e. $\mathrm{H}_{2} \mathrm{~S}$-producer organisms) found.

Table 2 shows the evolution of the target microorganisms during storage of the shrimp. Initial total bacteria counts were $3.2 \mathrm{log} \mathrm{cfu} / \mathrm{g}$. Newly caught shrimps with total bacteria counts between 2-3 log cycles (on Iron Agar or Long \& Hammer culture media) were considered high-quality (López-Caballero et al., 2002a). During the early days, the treatments inhibited total bacteria, especially in lot $\operatorname{HR}(\mathrm{p} \leq 0.05)$, with observable differences at the end of the period. Some authors have reported that formulations of 4hexylresorcinol at different concentrations reduced total viable counts in shrimp (Martínez-Álvarez et al 2005a; López-Caballero et al., 2007) and in tiger prawns (Martínez-Álvarez et al 2007) better than conventional treatments with commercial sulphites. On the contrary, 4-hexylresorcinol (0.01 and 0.1\%) did not show any antimicrobial effect on shrimps (X. kroyeri) during chilled storage at $0{ }^{\circ} \mathrm{C}$ (Galvão et al., 2017). About chitosan, Yuan et al, (2016b) reported inhibition of total flora in shrimp treated with chitosan over 9 days of storage on ice. López-Caballero et al. (2006b) found that chitosan treatment in iced prawns reduced total flora by almost 2 log cycles as compared to sulphite treated prawns, although these differences decreased as storage progressed. In the present work, chitosan was incorporated as a sulphite coadjutant, but this did not effectively inhibit total flora from $6 \mathrm{~d}$ onward $(\mathrm{p} \leq 0.05)$.

$\mathrm{H}_{2} \mathrm{~S}$-producing organisms, including Shewanella putrefaciens (López-Caballero et al., $2002 \mathrm{~b}$ ), were below the limit of detection $(<2 \log \mathrm{cfu} / \mathrm{g})$ in all batches up to $8 \mathrm{~d}$. This group of microorganisms seemed to be sensitive to 4-HR, since they could not be detected during storage, but they grew in all the other lots. However, higher values of this group have been registered in chilled lobsters treated with 4-hexylresorcinol than the control (sulphites) at day 7 of storage (López-Caballero et al., 2006a). These results could be due to differences between species (lobster and shrimp). Nirmal and Benjakul (2009) reported that the treatment of shrimp with $0.1 \%$ catechin solution delayed growth of $\mathrm{H}_{2} \mathrm{~S}$-producing bacteria during $10 \mathrm{~d}$ of storage (counts of 4.40 and $3.93 \mathrm{log}$ 
cfu/g for non-treated shrimp and shrimp treated with catechin, respectively). In this regard, Chanthachum et al., (1997) described that phenolic compounds might disrupt the cell wall of microorganisms by forming complexes with proteins in the cell wall causing the cell wall to lyse. Conventional sulphites, alone or in combination with chitosan, did not inhibit this microbial group (Table 2). In this connection, LópezCaballero et al. (2006b) reported that at $6 \mathrm{~d}$ iced prawns treated with chitosan registered counts $2 \log$ cycles lower than those treated with commercial sulphites, although this batch resumed growth up to $\approx 6 \log \mathrm{cfu} / \mathrm{g}$ at $12 \mathrm{~d}$ of storage. Arancibia et al., (2015) reported that the application of a chitosan coating in shrimp reduced $\mathrm{H}_{2} \mathrm{~S}$-producers by 2 log cycles during storage compared to the sulphites lots.

Luminescent colonies, presumptive Photobacterium phosphoreum (López-Caballero 2002a), were detected at 3 d. Lot HR registered the highest values at the end of the period, with $4.5 \log \mathrm{cfu} / \mathrm{g}(\mathrm{p} \leq 0.05)$. The formulations based on $4-\mathrm{HR}$ inhibited $P$. phosphoreum during iced storage of shrimp (Martínez-Álvarez 2005a). It could also be the case that the presence of this species was underestimated (especially in AF and S lots) since in some cases the strains did not shine and/or lost their luminescence over time.

The genus Pseudomonas registered a latency period until after 6 days, and from then on resumed growth up to more than $5 \log$ in lots $\mathrm{S}$ and $\mathrm{S}$-Ch (sulphites alone or in combination with chitosan) at the end of storage. In this regard, Arancibia et al. (2015) reported that chitosan films did not inhibit the growth of Pseudomonas spp. in refrigerated prawns This was attributed to the protection exerted by the outer membrane of Gram-negative cells (Coma et al., 2003), although some authors have stated that the action mechanism of chitosan could be related to disruption of the lipopolysaccharide layer of the outer membrane of Gram-negative bacteria (Helander et al., 2001). The lot treated with resorcinol presented counts similar to those of the control lot $(\mathrm{p} \leq 0.05)$.

Pseudomonas sp. counts were higher than counts of $\mathrm{H}_{2} \mathrm{~S}$-producers and closer to total flora counts (Table 2). Given that both groups dominate during storage of seafood on ice (López-Caballero et al., 2006a), in the present case the results suggest pseudomonads dominate during storage, irrespective of the treatment. The pseudomonad genus dominates the microbiota during storage of shrimp (LópezCaballero et al., 2006b). The low lactic bacteria values were probably due to the low storage temperature attained in ice storage. This was especially pronounced in lot HR $(\mathrm{p} \leq 0.05)$. One could expect that the growth of lactic acid bacteria would be favoured by 
the organic acids included in the formulations or in the S-Ch lot due to the acid in which the chitosan is dissolved. A formulation containing 4-hexylresorcinol $(0.1 \%)$ in lobster (López-Caballero et al., 2006a) and chitosan in prawns (López-Caballero et al., 2006b) stimulated the growth of lactic acid bacteria during storage. However, in the present work, the $\mathrm{pH}$ was similar in all lots, with counts $\leq 2 \log \mathrm{cfu} / \mathrm{g}$ for these mentioned lots at the end of storage. Enterobacteriaceae, indicators of faecal contamination, registered values $\leq 2 \mathrm{cfu} / \mathrm{g}$ during storage. These counts would indicate good quality of the raw material and good practice during handling for the application of treatments.

The counts of microorganisms found in this experiment could be related to the low level of amines (both biogenic and volatile) found. During storage of fish and crustaceans, the counts of spoiler organisms have to reach a certain level to produce biochemical changes that are perceptible and manifest at a sensory level. In the present work, it was estimated that endogenous enzymes contributed to the production of basic compounds and increased $\mathrm{pH}$, since spoiler counts were around $\leq 5.1 \log \mathrm{cfu} / \mathrm{g}$. With counts of $7 \log$ cfu/g (presumably $P$. phosphoreum), López-Caballero et al. (2002c) reported a high concentration of biogenic and volatile amines $(\approx 50 \mathrm{mg}$ TMA-N/100 $\mathrm{g}$ and $\approx 90 \mathrm{mg}$ TMA-N/100 g) during storage of iced prawn.

Diphenoloxidase activity during chilled storage was highest in additive-free shrimps (lot AF) during the first eight days of storage. Thus, activity remained constant for the first eight days after capture (Fig. 1), but from then on it decreased rapidly ( $\mathrm{P} \leq 0.05)$. A similar trend was observed by López-Caballero et al. (2007) in thawed shrimp. This activity seemed to be due to active PPO and haemocyanin $(\mathrm{Hc})$, which are the main responsible for diphenoloxidase activity in this crustacean specie (Martínez-Alvarez et al., 2008). In live deepwater pink shrimp, PPO exists as zymogen (proPPO) and Hc is responsible for oxygen transport. Post mortem and during the storage, $\mathrm{Hc}$ is converted into a diphenoloxidase-like enzyme (Martínez-Alvarez et al., 2008), and PPO is activated by proteolytic enzymes from the digestive tract (Gonzalves and Menezes de Oliveira, 2016). At the same time, PPO and Hc are irreversibly inactivated during the oxidation of substrate to product (Ramírez et al, 2003). The decrease in the diphenoloxidase activity after eight days of storage could be explained by the higher inactivation of both PPO and activated Hc when compared with the activation process.

The melanosis-inhibiting formulation HR strongly inhibited diphenoloxidase activity. However, the inhibition was not complete and in fact activity increased during the first 
eight days of storage, probably due to the appearance of new active forms of PPO and Hc during storage. The amount of this formula necessary to produce a complete inhibition of diphenoloxidase activity should then be higher than that tested in this work. Nonetheless, the formulation was effective in retarding the progress of melanosis (Fig. 2, 3), as previously reported in the same species (Martínez-Alvarez et al., 2007; Montero et al., 2004). Similar results were observed by López-Caballero et al. (2007) in thawed pink shrimp. This formulation includes antioxidant components such as ascorbic and citric acid that can irreversibly inactivate phenoloxidases and reduce o-dopaquinone to L-DOPA thus preventing the formation of melanin (Arias et al., 2007). As well, the protease inhibitors EDTA and PPi could delay conversion of proenzymes into diphenoloxidases. 4-hexylresorcinol is also known to produce inhibition of PPOs (Jiménez and García-Carmona, 1997) and active Hc (Adachi et al., 2001, 2005). In this regard, the melanosis inhibiting effect of 4-HR was described by Frankos et al. (1991), which described this compound as a competitive inhibitor of PPO "generally recognized as safe" (GRAS). 4-HR would produce strong inhibition of PPO due to the structural similarity between 4-HR and PPO substrates. 4-HR has been in fact described as a slow inhibitor (Jimenez and García-Carmona 1997) that binds preferentially intermediate forms of the enzyme catalytic cycle. The synergic effect of ascorbic acid and 4-HR has been described by Arias et al. (2007). These authors also observed that ascorbic acid seemed to be an irreversible inhibitor of PPO with ability to bind to the active site of the enzyme.

The S blend also inhibited diphenoloxidase activity. However, it was less effective than the HR formulation. Some authors have reported that sulphite derivatives can irreversibly inhibit PPO (Ferrer et al. 1989; Lambrecht, 1995; Ricquebourgh et al., 1996). They possibly interact with quinones to reduce coloured orthoquinones to colourless and less reactive diphenols (Lambrecht, 1995). Ascorbic acid may also act as a reducing agent, and citric acid and EDTA as chelators of copper at the enzyme-active site (Nirmal et al., 2015). In our work, the treatment of shrimp with a formulation including sodium metabisulphite (S) did not completely inactivate diphenoloxidase activity over storage, and in fact black spots were found three days after capture (Figure 3 ). This activity increased during the first 6 days of storage and decreased from then on. The commercial sulphite-based compound (S) was less effective at the outset of storage. Melanosis probably appeared in lot $\mathrm{S}$ because sulphites were gradually consumed and active diphenoloxidases were then able to oxidize natural substrates (mainly tyrosine 
and tyramine), thus allowing accumulation of melanin beneath the cuticle (Lambrecht, 1995; Riquebourg et al., 1996). The slight decline observed at the end of storage could be produced by the action of native proteases or by a natural inactivation process during oxidation of substrate to product (Ramírez et al, 2003).

Interestingly, the incorporation of chitosan in the sulphite-based formulation produced greater inhibition of diphenoloxidase activity during the first six days of storage (Fig. 1). This suggests a synergistic effect between chitosan and the components of the sulphite-based formulation. The inhibitory effect of chitosan against diphenoloxidases could be attributed to the chelating (No and Meyers, 2007; Simpson et al, 1997), antioxidant and oxygen barrier properties of chitosan (Huang et al., 2012). After shrimp is dipped in the chitosan solution, the modified atmosphere created by the chitosan could exclude oxygen, required as a reactant in the enzymatic browning reaction catalysed by polyphenol oxidases (Simpson et al, 1997).

The melanosis score reflected the appearance of black spots in all samples throughout chilled storage. However, important differences were observed among samples (Fig. 2). In the third day of storage, the non-treated shrimp and those treated with the formula $S$ showed an intense presence of black spots in the cuticle, produced by the diphenoloxidase activity of Hc and PPO. In contrast, the lot treated with the formulation including 4-hexylresorcinol did not show any presence of black spots in cuticle and was considered as the lot with the best appearance (Fig. 2, 3). Thus, the slight diphenoloxidase activity observed in this lot was not enough to produce a relevant production of melanins. Galvão et al., (2017) reported that the degree of melanosis in $X$. kroyeri was acceptable for 6 and even 12 days after treatment with $0.01 \%$ and $0.1 \%$ hexylresorcinol, respectively. Melanosis-inhibiting effect of similar 4-HR-based formulations to that used in the present work has also been reported in tiger prawns (Martínez-Alvarez et al., 2005b) and Norway lobster (López-Caballero et al., 2006a), and again could be attributed to the coadjutant effect of organic acids and chelants. After six days of storage, all lots were viewed as grey/black except for HR lot. The 4HR-based formula delayed blackening for three more days, but thereafter a greenish coloration appeared on the shrimp shell (Fig. 3, Table 4a). This colouration could be due to a certain degradation of the connective tissue beneath the cuticle of the cephalothorax produced by the acidic conditions of the 4-HR-based formulation. This degradation would make the cuticle more transparent and hence viscera more visible. 
The greenish coloration could be responsible for a loss of acceptability as important as the appearance of black spots. Several panellists considered that this could be due to natural changes in the red-green-grey colour of the viscera, which could not be seen at all in the control lot due to melanosis. In this regard, Martínez-Alvarez et al. (2007) and López Caballero et al., (2007) also observed similar greenish colouration in Norway lobster and thawed shrimp treated with a similar formula, respectively.

The formulations including sodium metabisulphite failed to maintain the good appearance of shrimps for more than three days (Figs. 2), at least at the concentration tested. Sodium metabisulfite (1.25 and $2.5 \%)$ slowed down significantly the melanosis of shrimps ( $X$. kroyeri), until 4-5 days, but thereafter no significant differences were shown with control shrimps, exhibiting all of them a severe degree of melanosis (Galvão et al., 2017). PPO is more active in autumn than in winter (Bono et al., 2010), which could explain the low effectiveness of the sulphite-based formulations at the concentration tested in the present work. Martínez-Alvarez et al., (2005a) noticed that dusting shrimp captured in autumn with the same concentration of commercial metabisulphite delayed the appearance of melanosis for at least 4 days. That is, dusting is better than immersion to prevent the appearance of melanosis in deepwater pink shrimp. The incorporation of chitosan in the sulphite-based formulation improved the appearance of shrimp, although it failed to prevent the appearance of black spots. Similar results were reported by Varlik et al. (2014). Alparslan and Baygar (2017) reported that chitosan films effectively inhibited melanosis in pink shrimp as compared with a control sample. Nonetheless, these authors also noted that the chitosan films did not completely prevent the appearance of black spots in treated shrimp. Yuan et al. (2016b) and Arancibia et al. (2015) also reported an inhibitory effect of chitosan coating on melanosis development in Pacific white shrimp. Guan-li et al. (1996) reported that chitosan could form a film on the surface of tiger shrimp, preventing oxidation and retarding the appearance of black spots.

The inhibition of diphenoloxidase activity was similar in formulations including either 4-hexylresorcinol or chitosan (Fig. 1) at the concentrations tested; however, the occurrence of black spots was much greater in shrimp treated with the formula including chitosan. The best aspect of the shrimp treated with the HR formula could be attributed to the presence of organic acids with the capacity to reduce quinones and thus avoid the formation of melanin. This suggests that factors other than enzymatic activity are important in the appearance of black spots in crustaceans. 
Initially, when applying the different melanosis-inhibiting formulas, no change in the colour of the shrimp was detected. Shrimp treated with the 4-hexylresorcinol-based formula registered the highest lightness $\left(\mathrm{L}^{*}\right)$ and whiteness $\left(\mathrm{W}^{*}\right)$ throughout chilled storage (Table 3). Similar results were reported by Varlik et al. (2014). Both lightness and whiteness remained stable throughout storage, mainly because of a lower prevalence of black spots on the shell. This lot registered the highest redness $\left(\mathrm{a}^{*}\right)$ during the first six days of storage $(p \leq 0.05)$, indicating that the shrimp retained their characteristic pink colour. However, redness decreased significantly from then on because of the appearance of green coloration in the shell, as previously observed in thawed shrimp (López-Caballero et al., 2007). For its part, yellowness increased slightly over storage.

Lightness, redness and whiteness declined significantly over time in shrimp non-treated with the HR formula. On the other hand, the evolution of yellowness differed between control and sulphite-treated samples. Thus, yellowness of control shrimp increased during storage, while in sulphite-treated samples it remained stable or decreased with time $(\mathrm{p} \leq 0.05)$.

We should note a high correlation between melanosis and certain colour parameters in some samples. Thus, when melanosis and lightness were plotted in HR samples, the polynomial correlation reached $\mathrm{R}^{2}=0.9955$. This suggests that perception of lightness was very important for the panellists to evaluate the progress of melanosis in this lot. At the same time, melanosis scores showed a very high polynomial correlation with lightness $\left(R^{2}=0.9998\right)$, whiteness $\left(R^{2}=0.9995\right)$, yellowness $\left(R^{2}=0.9975\right)$ and redness $\left(\mathrm{R}^{2}=0.9964\right)$ of $\mathrm{S}-\mathrm{Ch}$ samples. In contrast, in $\mathrm{AF}$ and $\mathrm{S}$ samples the polynomial correlation between melanosis and lightness, whiteness and redness was low, while the highest was with yellowness $\left(\mathrm{R}^{2}=0.9208\right.$ for $A F$ sample and $\mathrm{R}^{2}=0.9655$ for $\mathrm{S}$ samples). These correlations suggest that colour determination could be a useful tool to assess, on board or at the market, whether treated shrimp would be rejected or not by the consumers.

As for odour, at the beginning of the trial all lots scored 5 points (sea odour, fresh, algae) (Table 4b). As storage progressed, the score decreased indicating a loss of initial freshness. At 8 days, the HR lot scored close to 3 (neutral odour) while the other lots 
scored values closer to 2 (slight ammonia-like odour). At the end of the experimental period, the odour in all the other lots was qualified as slight ammonia/off-odour, mainly the lot S. The slight ammonia-like odour was not related to the microbiological results obtained in this work. Hence, this odour was much more related to the moderate TVB-N levels measured in all lots at the end of the storage. Nonetheless, the odour was not the most determinant organoleptic parameter to induce rejection, unlike the colour and integrity of individual shrimps (cephalothorax-tail union, Table 4c). Although the integrity of all shrimps was similar in all lots during the storage, a higher amount of individuals in lot HR remained whole at the end of the storage (Table 4c). The manipulation that implies the treatment with formulations $\mathrm{S}$ and $\mathrm{S}-\mathrm{Ch}$ (immersion, rinsing and placing in boxes with ice) could soften the cuticle and thus facilitated separation at the end of the storage. Regarding the control sample, the excision of the cephalothorax from the tail could be related to a potentially higher autolytic activity produced in absence of inhibitors of proteases.

To sum up, the application by spraying of a 4-hexylresorcinol-based formulation to shrimp was more effective than $3 \%$ of commercial sulphite solutions in preventing melanosis during autumn season. This treatment enhanced the duration of sensory acceptability of shrimp by up to six days of cold storage. The 4-hexylresorcinol-based formula inhibited the $\mathrm{H}_{2} \mathrm{~S}$-producing spoiler organisms, which were below the detection limit during storage, and also the genus Pseudomonas spp., thus presumably prolonging shelf-life. For these reasons, a 4-hexylresorcinol-based formula including chelants could be a real alternative to the use of sulphites for freshly caught deepwater pink shrimp and subsequent storage thereof. In general terms, the addition of $0.3 \%$ chitosan to sulphites used by immersion did not produce a clear improvement during further chilled storage of shrimp.

\section{ACKNOWLEDGMENTS}

This research was financed by the Spanish Ministry of Economy and Competitiveness (projects AGL2011-27607, AGL2014-52825-R). ICTAN-CSIC has implemented and maintains a Quality Management System which fulfils the requirements of the ISO standard 9001:2000.

\section{REFERENCES}


Adachi, K., Endo, H., Watanabe, T., Nishioka, T., Hirata, T. 2005. Hemocyanin in the exoskeleton of crustaceans: enzymatic properties and immunolocalization. Pigment Cell Research 18: 136-143.

Adachi, K., Hirata, T., Nagai, K., Sakaguchi, M. 2001. Hemocyanin a most likely inducer of black spots in Kuruma prawn Penaeus japonicus during storage. Journal of Food Science, 66:1130-1136.

Alparslan Y. and Baygar T. 2017. Effect of Chitosan Film Coating Combined with Orange Peel Essential Oil on the Shelf Life of Deepwater Pink Shrimp. Food and Bioprocess Technology 10 (5): 842-853.

Antonacopoulos, N. Vyncke, W. 1989. Determination of volatile basic in fish. Zeitschrift fur Lebensmittel-Untersuchung und-Forschung, 189, 309-316.

Arancibia, M.Y., López-Caballero, ME., Gómez-Guillén, MC., Montero, P. 2015. Chitosan coatings enriched with active shrimp waste for shrimp preservation. Food Control, 54:259-266.

Arias, E., González, J., Peiró, J. M., Oria, R., Lopez-Buesa, P. 2007. Browning prevention by ascorbic acid and 4-hexylresorcinol: Different mechanisms of action on polyphenol oxidase in the presence and in the absence of substrates. Journal of Food Science, 72(9), C464-C470.

Bono, G., Badalucco, C., Corrao, A., Cusumano, S., Mammina, L. Palmegiano, G.B. 2010. Effect of temporal variation, gender and size on cuticle polyphenol oxidase activity in deep-water rose shrimp (Parapenaeus longirostris). Food Chemistry 123:489493.

Coma V, Deschamps A, Martial-Gros A. 2003. Bioactive Packaging Materials from Edible Chitosan Polymer-Antimicrobial Activity Assessment on Dairy-Related Contaminants. Journal of Food Science 68(9):2788-2792. 
Chanthachum, S.; Beuchat, L. R. 1997. Inhibitory effect of kiam (Cotylelobium Ianceotatum craih) wood extract on gram positive food-borne pathogens and spoilage micro-organisms. Food Microbiology, 14: 603-608.22

EUMOFA (European Market Observatory for Fisheries and Aquaculture Products). EU consumer habits regarding fishery and aquaculture products. Final report. 2017, https://www.eumofa.eu/documents/20178/84590/EU+consumer+habits_final+report+.p df/5c61348d-a69c-449e-a606-f5615a3a7e4c.

European Parliament and Council Directive No 95/2/EC of 20 February 1995 on food additives other than colours and sweeteners. Official Journal L 061, 18/03/1995 P. 0001 0040 http://eur-lex.europa.eu/legalcontent/EN/TXT/HTML/?uri=CELEX:31995L0002\&from=ES

European Commission. 2014. Directorate-General for Agriculture and Rural Development. B.4. Organics. Expert Group for Technical Advice on Organic Production. Mandate for Technical Advice on Organic Food (iii). 20141014, pp 3.

Fingerman, M., Nagabhushanam, R., Sarojini, R., Reddy, P.S. 1994. Biogenic amines in crustaceans: identification, localization, and roles. Journal of Crustaceans Biology, $14: 413-437$.

Frankos, V.H., Schmitt, D.F., Haws, L.C., McEvily, A.J., Iyengar, R., Iller, S.A., Munro, I.C., Clydesdale, F.M., Forbes, A.L., \& Sauer, R.M. 1991. Generally Recognised As Safe (GRAS) evaluation of 4-hexylresorcinol for use as a processing aid for prevention of melanosis in shrimp. Regulatory Toxicology and Pharmacology, 14: 202-212.

Galvão, J.A., Vázquez-Sánchez, D., Yokoyama, V.A., Savay-da-silva, L.K., Brazaca, S.G.C., Oetterer, M. 2017. Effect of 4-hexylresorcinol and sodium metabisulphite on spoilage and melanosis inhibition in xiphopenaeus kroyeri shrimps. Journal of Food Processing and Preservation, 41, 13pp. 
Gonzalves, A.A. and Menezes de Oliveira, A.R. 2016. Melanosis in crustaceans: A review. LWT - Food Science and Technology 65:791-799.

Guan-li, Y., Yuang-Hong, W., Shu-Qing, L., Xue-lin, T. 1996. Effects of low molecular weight chitosan (LMC-1) on shrimp preservation. Chinese Journal of Oceanology and Limnology 14 (2):189-192.

Helander IM, Nurmiaho-Lassila EL, Ahvenainen R, Rhoades J, Roller S. 2001. Chitosan disrupts the barrier properties of the outer membrane of Gram-negative bacteria. International Journal of Food Microbiology 71:235-244.

Huang, J., Chen, Q., Qiu, M., Li, S. 2012. Chitosan-based edible coatings for quality preservation of postharvest whiteleg shrimp (Litopenaeus vannamei). Journal of Food Science, 77(4), C491-C496.

Huidobro, A., López Caballero, E., Mendes, R. 2002. Onboard processing of deepwater pink shrimp (Parapenaeus longirostris) with liquid ice: Effect on quality European Food Research Technology, 214:469-475.

Jiménez, M., García-Carmona, F. 1997. 4-Substituted Resorcinols (Sulfite Alternatives) as Slow-Binding Inhibitors of Tyrosinase Catecholase Activity. Journal of Agriculture and Food Chemistry 45 (6):2061-2065.

Lambrecht, H.S. 1995. Sulfite substitutes for the prevention of enzymatic browning in foods. In: Enzymatic Browning and its Prevention (edited by C.Y. Lee \& J.R. Whitaker). Pp. 313-323. Washington, DC: American Chemical Society.

López-Caballero, ME., Gonçalves, A., Nunes, ML. 2002a. Effect of $\mathrm{CO}_{2} / \mathrm{O}_{2}$-containing modified atmospheres on packed deepwater pink shrimp (Parapenaeus longirostris). European Food Research Technology 214:192-197.

López-Caballero, ME., Sánchez-Fernández, J.A., Moral, A. 2002b. Growth and metabolic activity of Shewanella putrefaciens maintained under different $\mathrm{CO}_{2}$ and $\mathrm{O}_{2}$ concentrations. International Journal of Food Microbiology 64 (2001) 277-287. 
López-Caballero, ME., Álvarez-Torres, MD., Sánchez-Fernández, J.A., Moral, A. 2002c. Photobacterium phosphoreum isolated as a luminescent colony from spoiled fish, cultured in model system under controlled atmospheres. European Food Research Technology 215:390-395.

López-Caballero, ME; Martínez-Álvarez, O; Gómez-Guillén, MC; Montero P. 2006a. Quality of Norway lobster (Nephrops norwegicus) treated with a 4-hexylresorcinol based formulation. European Food Research and Technology, 222, 425-431.

López-Caballero, ME; Martínez-Álvarez, O; Gómez-Guillén, MC; Montero P. 2006b. Effect of natural compounds alternative to commercial antimelanosics on polyphenol oxidase activity and microbial growth in cultured prawns (Marsupenaeus tiger) during chilled storage. European Food Research and Technology, 223: 7-15.

López-Caballero, ME; Martínez-Alvarez, O; Gómez-Guillén MC, Montero P. 2007. Quality of thawed deepwater pink shrimp (Parapenaeus longirostris) treated with melanosis-inhibiting formulations during chilled storage. International Journal of Food Science and Technology, 42, 1029-1038.

Martínez-Alvarez, O., Gómez-Guillén, C., and Montero, P. 2005a. Role of sulfites and 4-hexilresorcinol in microbial growth and melanosis prevention of deepwater pink shrimps (Parapenaeus longirostris) using a controlled atmosphere. Journal of Food Protection, 68 (1): 98-104.

Martínez-Alvarez, O., Gómez-Guillén, C. and Montero, P. 2008. Presence of hemocyanin with diphenoloxidase activity in deepwater pink shrimp (Parapenaeus longirostris) post mortem. Food Chemistry, 107(4): 1450-1460.

Martínez-Álvarez, O., López-Caballero, M.E., Montero, P., Gómez-Guillén, M.C. 2007. Spraying of 4-hexylresorcinol based formulations to prevent enzymatic browning in Norway lobsters (Nephrops norvegicus) during chilled storage. Food Chemistry 100 (2007) 147-155. 
Martínez-Álvarez, O., López-Caballero, M.E., Montero, P., Gómez-Guillén, M.C. 2005b. A 4-hexylresorcinol-based formulation to prevent melanosis and microbial growth in chilled tiger prawns (Marsupenaeus japonicus) from aquaculture. Journal of Food Science 70(9):M415-M422.

Martínez-Alvarez, O., López-Caballero, ME., Gómez-Guillén, MC., Montero, P. 2009. The effect of several cooking treatments on subsequent chilled storage of thawed deepwater pink shrimp (Parapenaeus longirostris) treated with different melanosisinhibiting formulas. LWT - Food Science and Technology 42(8):1335-1344.

McEvily A.J., Iyengar R. and Otwell W.S. 1991. 4-Hexylresorcinol controls enzymatic browning in shrimp and has potential for application in a variety of other foods and beverages. Food Technology, 45:80-86.

Mendes, R., Huidobro, A., López Caballero, E. 2002. Indole levels in deepwater pink shrimp (Parapenaeus longirostris) from the Portuguese coast. Effects of temperature abuse. European Food Research Technology, 214:125-130.

Montero, P., Gómez-Guillén, M.C. Borderías, J. 1996. Influence of subspecies, season and stabilization procedures in gel-forming ability of frozen minced muscle of sardine (Sardina pilchardus). Food Science and Technology International, 2, 111-122.

Montero, P., Lopez-Caballero, M.E., Perez-Mateos, M. 2001. The effect of inhibitors and high pressure treatment to prevent melanosis and microbial growth on chilled prawns (Penaeus japonicus). Journal of Food Science, 66(8), pp. 1201-1206

Montero, P., Martínez-Álvarez, O., Gómez-Guillén, M.C. 2004. Effectiveness of onboard application of 4-hexylresorcinol in inhibiting melanosis in shrimp (Parapenaeus longirostris). Journal of Food Science, 68, 643-647.

Muxika, A., Etxabide, A., Uranga, J., Guerrero, P., de la Caba, K. 2017. Chitosan as a bioactive polymer: Processing, properties and applications. International Journal of Biological Macromolecules, 105(2):1358-1368. 
Nirmal, N.P., and Benjakul, S. Melanosis and quality changes of Pacific white shrimp (Litopenaeus vannamei) treated with catechin during iced storage. 2009. Journal of Agriculture and Food Chemistry. 57, 3578-3586.

Nirmal, N. P., Benjakul, S., Ahmad, M., Arfat, Y. A., Panichayupakaranant, P. 2015. Undesirable Enzymatic Browning in Crustaceans: Causative Effects and Its Inhibition by Phenolic Compounds. Critical Reviews in Food Science and Nutrition, 55(14): 19922003

No, H. K., Meyers, S. P., Prinyawiwatkul, W., Xu, Z. 2007. Applications of chitosan for improvement of quality and shelf life of foods: a review. Journal of Food Science, 72, R87-R100.

Park, J. W. 1994. Functional properties additives in surimi gels. Journal of Food Science, 59(3), 525-527.

Ramírez, E.C., Whitaker, J.R., Virador, V. 2003. Polyphenol oxidase. In: Handbook of Food Enzymology (edited by J.R. Whitaker, A.G.J. Voragen \& D.W.S. Wong). Pp. 509-523. New York, NY: Marcel Dekker, Inc.

Ricquebourgh, S.L., Robert-Da Silva, C.M.F., Rouch, C.C., Cadet, F.R. 1996. Theoretical support for a conformational change of polyphenol oxidase induced by metabisulfite. Journal of Agricultural and Food Chemistry, 44, 3457-3460.

Ritchie, A. H. 1991. The Torry Station method for biogenic amines by HPLC. Technical Report Torry Research Station, Aberdeen, Scotland.

Rolle, R. S., Guizani, N., Chen, J. S., Marshall, M. R, Yan, J. S., Wei, C. I. 1991. Purification and characterization of phenoloxidase isoforms from Taiwanese black tiger shrimp (Penaeus monodon). Journal of Food Biochemistry, 15, 17-32.

Rzepecki, L. M., \& Waite, J. H. 1989. A chromogenic assay for catecholoxidases based on the addition of L-proline to quinones. Analytical Biochemistry, 179, 375-381. 
Silla Santos, M.H. 1996. Biogenic amines: their importance in foods. International Journal of Food Microbiology, 29: 213-231.

Simpson BK, Gagné N, Ashie INA, Noroozi E. 1997. Utilization of chitosan for preservation of raw shrimp (Pandalus borealis). Food Biotechnology 11(1):25-44.

Statista.com, 2018. https://www.statista.com/statistics/443969/seafood-consumptionvolume-in-spain/. Last access 11-April-2018.

Timbo B., Koehler KM, Wolyniak C, Klontz KC. 2004. Sulfites--a food and drug administration review of recalls and reported adverse events. Journal Food Protection, 67(8):1806-11.2004.

Varlik, C., Bostan, K., Bingol, E.B. 2014. Effects of treatment with chitosan and antimelanogenesis agents on discoloration of chilled and frozen stored shrimp. Med. Weter., 70(6):362-368

Wang, Q., Lei, J., Ma, J., Yuan, G., Sun, H., 2018. Effect of chitosan-carvacrol coating on the quality of Pacific white shrimp during iced storage as affected by caprylic acid International Journal of Biological Macromolecules106, January 2018, 123-129.

Wang, Z. K. D., Taylor, A., Yan, X. 1992. Studies on the protease activities in Norway lobster (Nephrops norvegicus) and their role in the phenolase activation process. Food Chemistry, 45, 111-116.

Yuan, G., Lv H., Tang, W., Zhang, X., Sun, H. 2016a. Effect of chitosan coating combined with pomegranate peel extract on the quality of Pacific white shrimp during iced storage. Food Control, 59: 818-823.

Yuan, G., Lv H., Tang, W., Zhang, X., Sun, H. 2016b. Effect of chitosan coating combined with green tea extract on the melanosis and quality of Pacific white shrimp during storage in ice. Journal CyTA - Journal of Food, 14(1): 35-40. 


\section{Legends}

Figure 1: PPO activity (Units/ml extract) in deepwater pink shrimp during chilled storage.

HR: shrimp treated with 4-hexylresorcinol-based formulation; AF: No additives; S: commercial sulphite-based formulation; S-Ch: commercial sulphite-based formulation incorporated with Chitosan solution.

Figure 2. Melanosis score in deepwater pink shrimp during chilled storage.

HR: shrimp treated with 4-hexylresorcinol-based formulation; AF: No additives; S: commercial sulphite-based formulation; S-Ch: commercial sulphite-based formulation incorporated with Chitosan solution.

Figure 3. Aspect of deepwater pink shrimp treated with different melanosis-inhibiting formulations during eight days of ice storage. HR: shrimp treated with 4hexylresorcinol-based formulation; AF: No additives; S: commercial sulphite-based formulation; S-Ch: commercial sulphite-based formulation incorporated with Chitosan solution. 


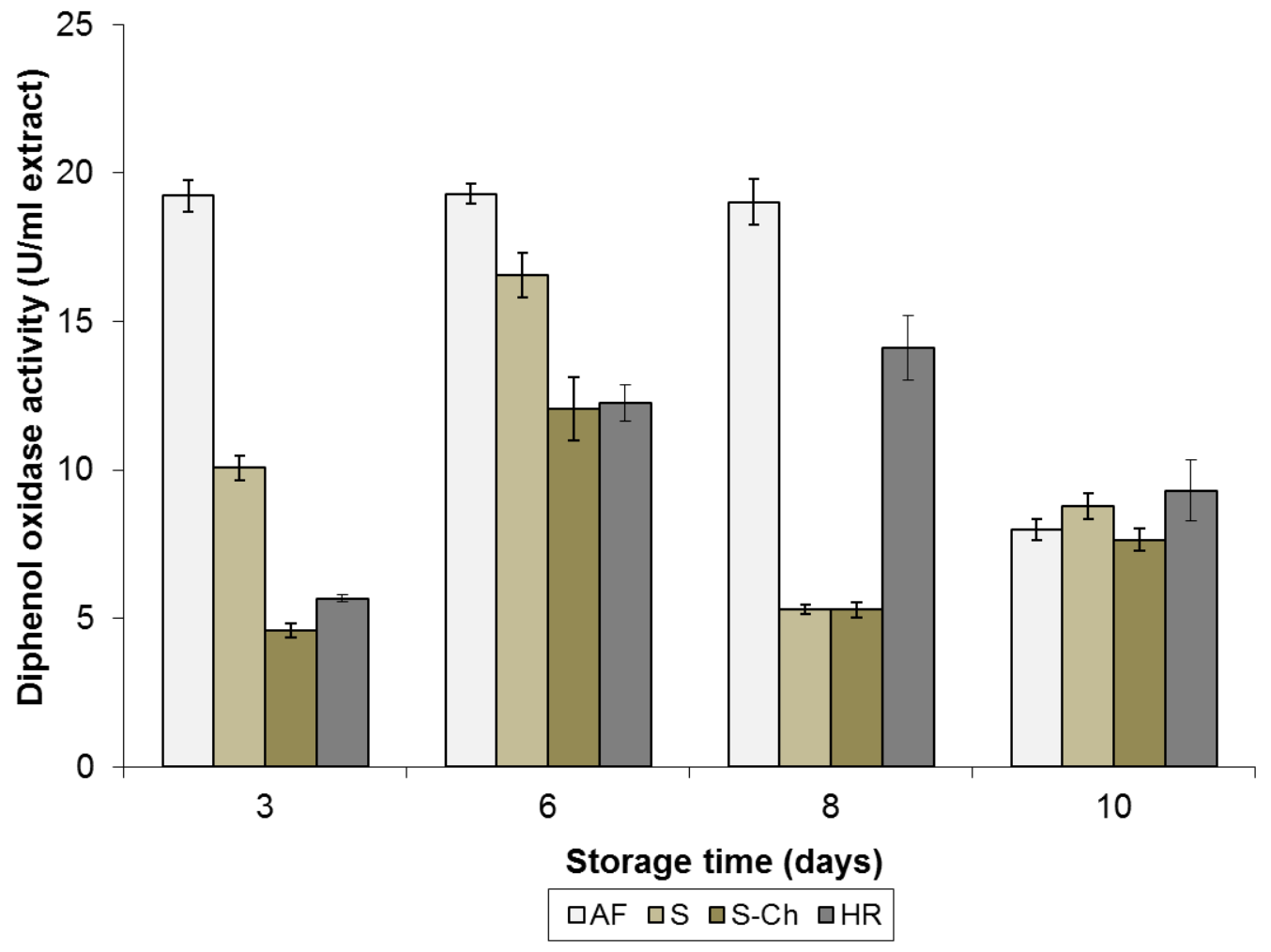

Figure 1 


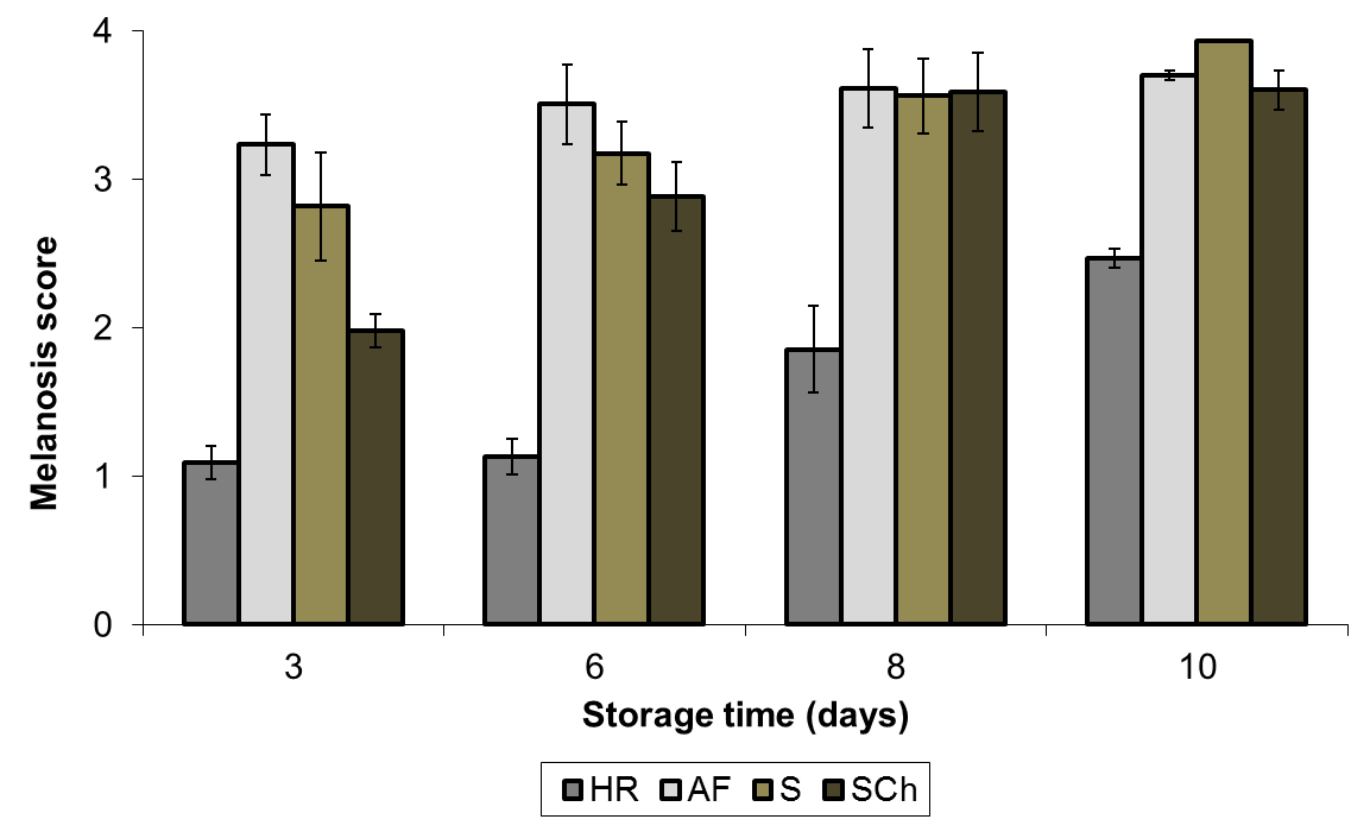

Figure 2 


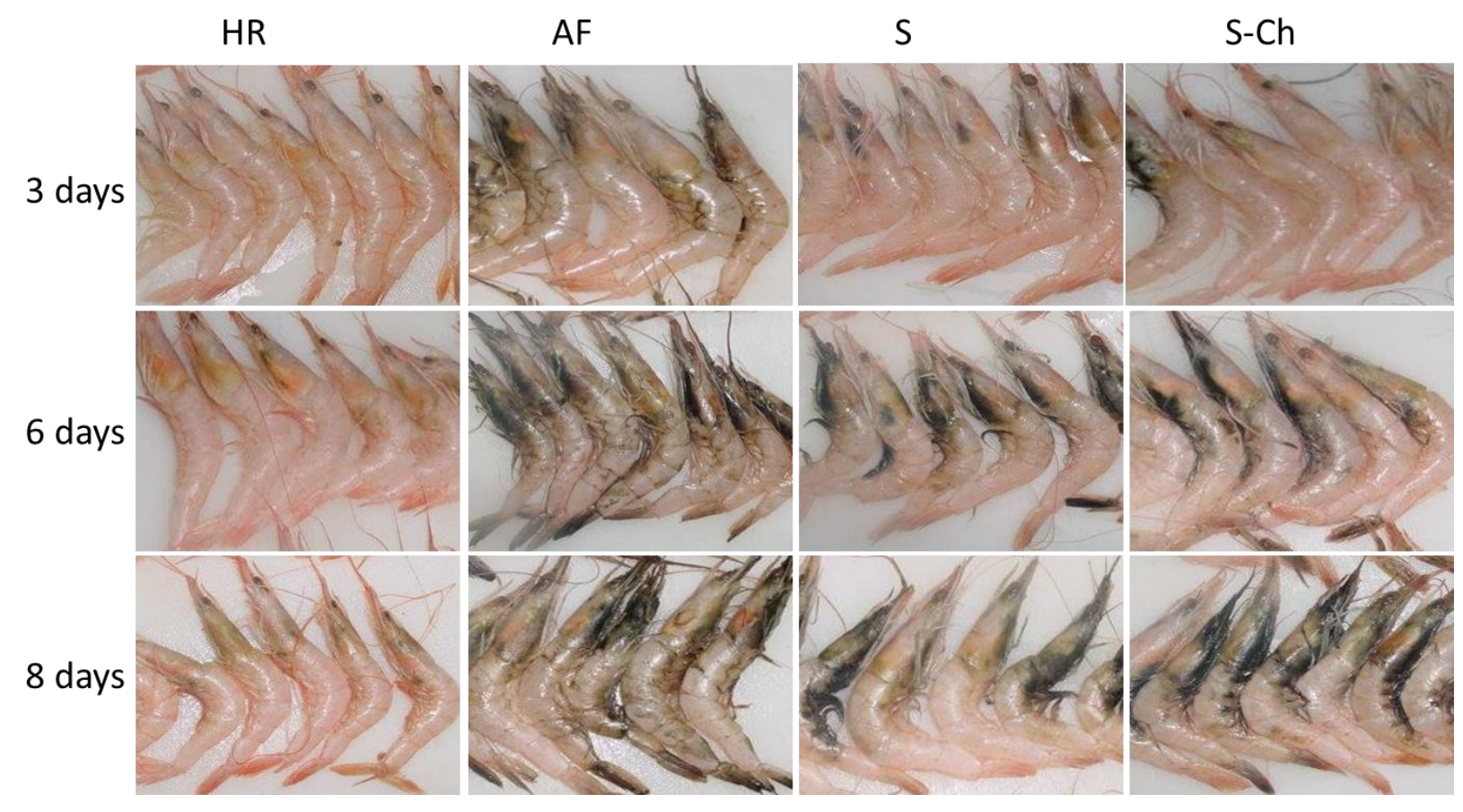

Figure 3 
Table 1. Total volatile basic nitrogen (TVB-N) content in deepwater pink shrimp during chilled storage.

\begin{tabular}{l|ccccc} 
Lots & 0 days & 3 days & 6 days & 8 days & 10 days \\
\hline AF & $29.3 \pm 0.1^{\text {d.x }}$ & $32.2 \pm 0.7^{\text {c.x }}$ & $36.0 \pm 0.5^{\text {c.y }}$ & $31.4 \pm 2.0^{\text {a.x }}$ & $28.5 \pm 2.4^{\text {a.x }}$ \\
S & $28.1 \pm 0.1^{\text {c.x }}$ & $30.5 \pm 0.8^{\text {bc.y }}$ & $35.5 \pm 0.5^{\text {c.t }}$ & $33.2 \pm 0.6^{\text {a.z }}$ & $29.8 \pm 2.3^{\text {a.xy }}$ \\
S-Ch & $27.4 \pm 0.1^{\text {b.x }}$ & $29.1 \pm 0.4^{\text {ab.xy }}$ & $30.4 \pm 1.0^{\text {a.y }}$ & $27.6 \pm 1.1^{\text {a.x }}$ & $28.2 \pm 1.8^{\text {a.x }}$ \\
HR & $26.3 \pm 0.1^{\text {a.x }}$ & $27.2 \pm 1.4^{\text {a.x }}$ & $33.8 \pm 0.5^{\text {b.y }}$ & $33.2 \pm 4.2^{\text {a.y }}$ & $33.6 \pm 1.6^{\text {b.y }}$
\end{tabular}

AF: no additives; S: commercial sulphites; S-Ch: commercial sulphites + chitosan; HR: formulation containing 4-hexylresorcinol $(0.1 \%)$, chelants and acids.

Different letters $(\mathrm{a}, \mathrm{b}, \mathrm{c} . .$.$) in the same column indicate significant differences (\mathrm{p} \leq 0.05)$ as a function of treatment; different letters $(\mathrm{x}, \mathrm{y}, \mathrm{z} \ldots)$ in the same row indicate significant differences $(\mathrm{p} \leq 0.05)$ as a function of storage time. 
Table 2. Microbiological counts in deepwater pink shrimp during chilled storage.

\begin{tabular}{|c|c|c|c|c|c|c|}
\hline Microorganisms & Lots & 0 days & 3 days & 6 days & 8 days & 10 days \\
\hline \multirow[t]{4}{*}{ Total bacteria count $\left(15^{\circ} \mathrm{C}\right)$} & $\mathbf{A F}$ & $3.2 \pm 0.2^{\mathrm{a}, \mathrm{x}}$ & $3.7 \pm 0.0^{\mathrm{b}, \mathrm{y}}$ & $4.2 \pm 0.1^{\mathrm{a}, \mathrm{z}}$ & $5.3 \pm 0.1^{\mathrm{a}, \mathrm{t}}$ & $6.0 \pm 0.1^{\mathrm{b}, \mathrm{w}}$ \\
\hline & $\mathbf{S}$ & $3.0 \pm 0.2^{\mathrm{a}, \mathrm{x}}$ & $4.1 \pm 0.1^{\mathrm{c}, \mathrm{y}}$ & $4.9 \pm 0.1^{\mathrm{b}, \mathrm{z}}$ & $5.6 \pm 0.0^{\mathrm{b}, \mathrm{t}}$ & $6.1 \pm 0.0^{\mathrm{b}, \mathrm{w}}$ \\
\hline & S-Ch & $3.1 \pm 0.2^{\mathrm{a}, \mathrm{x}}$ & $3.6 \pm 0.1^{\mathrm{b}, \mathrm{y}}$ & $4.1 \pm 0.2^{\mathrm{a}, \mathrm{z}}$ & $6.2 \pm 0.0^{\mathrm{d}, \mathrm{t}}$ & $6.6 \pm 0.1^{\mathrm{c}, \mathrm{w}}$ \\
\hline & HR & $3.0 \pm 0.2^{\mathrm{a}, \mathrm{x}}$ & $2.9 \pm 0.3^{\mathrm{a}, \mathrm{x}}$ & $4.0 \pm 0.1^{\mathrm{a}, \mathrm{y}}$ & $5.9 \pm 0.0^{\mathrm{c}, \mathrm{z}}$ & $5.4 \pm 0.3^{\mathrm{a}, \mathrm{t}}$ \\
\hline \multirow[t]{4}{*}{$\mathrm{H}_{2} \mathrm{~S}$-producers organisms } & $\mathbf{A F}$ & $<2$ & $<2$ & $<2$ & $3.7 \pm 0.4^{\mathrm{b}, \mathrm{x}}$ & $3.8 \pm 0.3^{\mathrm{a}, \mathrm{x}}$ \\
\hline & $\mathbf{S}$ & $<2$ & $<2$ & $<2$ & $3.2 \pm 0.2^{\mathrm{a}, \mathrm{x}}$ & $4.5 \pm 0.0^{\mathrm{ab}, \mathrm{y}}$ \\
\hline & S-Ch & $<2$ & $<2$ & $<2$ & $3.5 \pm 0.2^{\mathrm{ab}, \mathrm{x}}$ & $4.9 \pm 0.8^{\mathrm{b}, \mathrm{y}}$ \\
\hline & HR & $<2$ & $<2$ & $<2$ & $<2$ & $<2$ \\
\hline \multirow[t]{4}{*}{ Luminiscent colonies } & $\mathbf{A F}$ & $<2$ & $2.0 \pm 0.0^{\mathrm{a}, \mathrm{x}}$ & $2.7 \pm 0.5^{\mathrm{a}, \mathrm{y}}$ & $2.0 \pm 0.0^{\mathrm{a}, \mathrm{x}}$ & $2.0 \pm 0.0^{\mathrm{a}, \mathrm{x}}$ \\
\hline & $\mathbf{S}$ & $<2$ & $2.8 \pm 0.7^{\mathrm{b}, \mathrm{y}}$ & $3.5 \pm 0.3^{\mathrm{b}, \mathrm{z}}$ & $2.0 \pm 0.0^{\mathrm{a}, \mathrm{x}}$ & $2.0 \pm 0.0^{\mathrm{a}, \mathrm{x}}$ \\
\hline & S-Ch & $<2$ & $2.3 \pm 0.4^{\mathrm{ab}, \mathrm{x}}$ & $2.0 \pm 0.0^{\mathrm{a}, \mathrm{x}}$ & $2.0 \pm 0.0^{\mathrm{a}, \mathrm{x}}$ & $3.5 \pm 2.1^{\mathrm{ab}, \mathrm{x}}$ \\
\hline & HR & $<2$ & $2.2 \pm 0.2^{\mathrm{ab}, \mathrm{x}}$ & $2.5 \pm 0.7^{\mathrm{a}, \mathrm{x}}$ & $5.0 \pm 0.2^{\mathrm{b}, \mathrm{y}}$ & $4.5 \pm 0.1^{\mathrm{b}, \mathrm{y}}$ \\
\hline \multirow[t]{4}{*}{ Pseudomonas spp. } & $\mathbf{A F}$ & $2.1 \pm 0.2^{\mathrm{a}, \mathrm{x}}$ & $2.2 \pm 0.2^{\mathrm{a}, \mathrm{x}}$ & $2.2 \pm 0.2^{\mathrm{a}, \mathrm{x}}$ & $4.2 \pm 0.1^{\mathrm{c}, \mathrm{y}}$ & $3.9 \pm 1.3^{\mathrm{ab}, \mathrm{y}}$ \\
\hline & $\mathbf{S}$ & $2.0 \pm 0.0^{\mathrm{a}, \mathrm{x}}$ & $2.2 \pm 0.3^{\mathrm{a}, \mathrm{x}}$ & $2.2 \pm 0.3^{\mathrm{a}, \mathrm{x}}$ & $3.5 \pm 0.1^{\mathrm{a}, \mathrm{y}}$ & $5.1 \pm 0.1^{\mathrm{b}, \mathrm{z}}$ \\
\hline & S-Ch & $2.2 \pm 0.0^{\mathrm{a}, \mathrm{x}}$ & $2.2 \pm 0.2^{\mathrm{a}, \mathrm{x}}$ & $2.2 \pm 0.2^{\mathrm{a}, \mathrm{x}}$ & $4.2 \pm 0.0^{\mathrm{c}, \mathrm{y}}$ & $5.1 \pm 0.1^{\mathrm{b}, \mathrm{z}}$ \\
\hline & HR & $2.0 \pm 0.0^{\mathrm{a}, \mathrm{x}}$ & $2.7 \pm 0.5^{\mathrm{a}, \mathrm{y}}$ & $2.7 \pm 0.5^{\mathrm{a}, \mathrm{y}}$ & $3.9 \pm 0.1^{\mathrm{b}, \mathrm{z}}$ & $3.8 \pm 0.0^{\mathrm{a}, \mathrm{z}}$ \\
\hline \multirow[t]{4}{*}{ Lactic acid bacteria } & $\mathbf{A F}$ & $2.0 \pm 0.2^{\mathrm{a}, \mathrm{y}}$ & $2.8 \pm 0.1^{\mathrm{c}, \mathrm{z}}$ & $2.0 \pm 0.2^{\mathrm{b}, \mathrm{y}}$ & $1.7 \pm 0.3^{\mathrm{a}, \mathrm{x}}$ & $2.6 \pm 0.1^{\mathrm{d}, \mathrm{z}}$ \\
\hline & $\mathbf{S}$ & $2.2 \pm 0.2^{\mathrm{a}, \mathrm{y}}$ & $1.7 \pm 0.3^{\mathrm{a}, \mathrm{x}}$ & $2.2 \pm 0.2^{\mathrm{b}, \mathrm{y}}$ & $1.6 \pm 0.4^{\mathrm{a}, \mathrm{x}}$ & $2.4 \pm 0.0^{\mathrm{c}, \mathrm{y}}$ \\
\hline & S-Ch & $2.1 \pm 0.2^{\mathrm{a}, \mathrm{x}}$ & $2.4 \pm 0.1^{\mathrm{b}, \mathrm{x}}$ & $2.1 \pm 0.2^{\mathrm{b}, \mathrm{x}}$ & $2.4 \pm 0.0^{\mathrm{b}, \mathrm{x}}$ & $2.1 \pm 0.2^{\mathrm{b}, \mathrm{x}}$ \\
\hline & HR & $2.1 \pm 0.2^{\mathrm{a}, \mathrm{t}}$ & $1.6 \pm 0.2^{\mathrm{a}, \mathrm{z}}$ & $1.5 \pm 0.1^{\mathrm{a}, \mathrm{yz}}$ & $1.2 \pm 0.3^{\mathrm{a}, \mathrm{xy}}$ & $1.0 \pm 0.0^{\mathrm{a}, \mathrm{x}}$ \\
\hline \multirow[t]{4}{*}{ Enterobacteriaceae } & $\mathbf{A F}$ & $1.3 \pm 0.1^{\mathrm{a}, \mathrm{y}}$ & $1.2 \pm 0.2^{\mathrm{a}, \mathrm{xy}}$ & $1.0 \pm 0.0^{\mathrm{a}, \mathrm{x}}$ & $1.2 \pm 0.2^{\mathrm{a}, \mathrm{xy}}$ & $1.0 \pm 0.0^{\mathrm{a}, \mathrm{x}}$ \\
\hline & $\mathbf{S}$ & $1.1 \pm 0.1^{\mathrm{a}, \mathrm{x}}$ & $1.5 \pm 0.6^{\mathrm{a}, \mathrm{x}}$ & $2.3 \pm 0.1^{\mathrm{c}, \mathrm{y}}$ & $1.2 \pm 0.2^{\mathrm{a}, \mathrm{x}}$ & $1.3 \pm 0.4^{\mathrm{a}, \mathrm{x}}$ \\
\hline & S-Ch & $1.4 \pm 0.1^{\mathrm{a}, \mathrm{x}}$ & $1.5 \pm 0.7^{\mathrm{a}, \mathrm{x}}$ & $1.5 \pm 0.2^{\mathrm{b}, \mathrm{x}}$ & $1.5 \pm 0.0^{\mathrm{b}, \mathrm{x}}$ & $1.5 \pm 0.6^{\mathrm{a}, \mathrm{x}}$ \\
\hline & HR & $1.0 \pm 0.1^{\mathrm{a}, \mathrm{y}}$ & $1.0 \pm 0.0^{\mathrm{a}, \mathrm{x}}$ & $1.3 \pm 0.4^{\mathrm{ab}, \mathrm{xy}}$ & $1.0 \pm 0.0^{\mathrm{a}, \mathrm{x}}$ & $2.4 \pm 0.1^{\mathrm{b}, \mathrm{z}}$ \\
\hline
\end{tabular}

AF: no additives; S: commercial sulphites; S-Ch: commercial sulphites + chitosan; HR: formulation containing 4-hexylresorcinol $(0.1 \%)$, chelants and acids.

Detection limit: $<2 \mathrm{log} \mathrm{cfu} / \mathrm{g}$ for total bacteria count, $\mathrm{H}_{2} \mathrm{~S}$-producing microorganisms, luminescent colonies and Pseudomonas spp; <1 log cfu/g for lactic acid bacteria and Enterobacteriaceae.

Different letters $(\mathrm{a}, \mathrm{b}, \mathrm{c} . .$.$) in the same column indicate significant differences (\mathrm{p} \leq 0.05)$ as a function of treatment; different letters $(x, y, z \ldots)$ in the same row indicate significant differences $(\mathrm{p} \leq 0.05)$ as a function of storage time. 
Table 3. Evolution of colour parameters in deepwater pink shrimp treated with different melanosis-inhibiting formula throughout chilled storage

\begin{tabular}{|c|c|c|c|c|c|}
\hline & & 3 days & 6 days & 8 days & 10 days \\
\hline \multirow{4}{*}{$\mathbf{L}^{*}$} & $\mathbf{A F}$ & $40.96 \pm 2.21^{\mathrm{a} / \mathrm{x}}$ & $41.40 \pm 0.89^{\mathrm{a} / \mathrm{x}}$ & $44.34 \pm 0.77^{\mathrm{a} / \mathrm{y}}$ & $49.17 \pm 1.69^{\mathrm{a} / \mathrm{y}}$ \\
\hline & $\mathbf{S}$ & $53.13 \pm 1.71^{\mathrm{b} / \mathrm{x}}$ & $48.53 \pm 1.03^{\mathrm{b} / \mathrm{y}}$ & $42.90 \pm 1.71^{\mathrm{a} / \mathrm{z}}$ & $46.74 \pm 1.01^{\mathrm{b} / \mathrm{z}}$ \\
\hline & S-Ch & $49.51 \pm 1.07^{\mathrm{c} / \mathrm{x}}$ & $45.28 \pm 1.40^{\mathrm{c} / \mathrm{y}}$ & $39.66 \pm 0.93^{\mathrm{c} / \mathrm{z}}$ & $39.86 \pm 0.85^{\mathrm{c} / \mathrm{y}}$ \\
\hline & HR & $55.27 \pm 1.50^{\mathrm{d} / \mathrm{x}}$ & $54.66 \pm 1.40^{\mathrm{d} / \mathrm{x}}$ & $57.74 \pm 0.47^{\mathrm{d} / x y}$ & $59.03 \pm 1.63^{\mathrm{d} / \mathrm{z}}$ \\
\hline \multirow{4}{*}{$\mathbf{a}^{*}$} & $\mathbf{A F}$ & $-0.69 \pm 0.83^{a / x}$ & $-0.78 \pm 1.38^{a / x y}$ & $-1.52 \pm 0.32^{a b / x y}$ & $-2.01 \pm 0.69^{a / y}$ \\
\hline & $\mathbf{S}$ & $-0.89 \pm 0.75^{\mathrm{a} / \mathrm{x}}$ & $-1.51 \pm 0.75^{a / x y}$ & $-2.73 \pm 0.89^{b / y}$ & $-0.94 \pm 1.18^{b c / x y}$ \\
\hline & S-Ch & $0.19 \pm 1.15^{\mathrm{a} / \mathrm{x}}$ & $-1.86 \pm 0.49^{\mathrm{a} / \mathrm{y}}$ & $-2.24 \pm 0.43 \mathrm{ab} / \mathrm{y}$ & $-2.19 \pm 1.32^{\mathrm{ab} / \mathrm{y}}$ \\
\hline & HR & $1.97 \pm 0.47^{\mathrm{b} / \mathrm{xy}}$ & $2.33 \pm 0.51^{\mathrm{b} / \mathrm{y}}$ & $-0.99 \pm 0.64^{\mathrm{a} / \mathrm{z}}$ & $0.79 \pm 1.20^{\mathrm{c} / \mathrm{xz}}$ \\
\hline \multirow{4}{*}{$\mathbf{b}^{*}$} & $\mathbf{A F}$ & $8.50 \pm 1.85^{\mathrm{a} / \mathrm{x}}$ & $13.06 \pm 1.93^{\mathrm{a} / \mathrm{y}}$ & $17.41 \pm 0.41^{\mathrm{a} / \mathrm{z}}$ & $16.45 \pm 0.59^{\mathrm{a} / \mathrm{z}}$ \\
\hline & & $15.65 \pm 0.39^{\mathrm{b} / \mathrm{x}}$ & $16.06 \pm 1.55^{\mathrm{b} / \mathrm{x}}$ & $16.41 \pm 1.75 \mathrm{ab} / \mathrm{x}$ & $16.20 \pm 0.67^{\mathrm{a} / \mathrm{x}}$ \\
\hline & S-Ch & $19.32 \pm 1.43^{\mathrm{c} / \mathrm{x}}$ & $17.19 \pm 0.89^{\mathrm{b} / \mathrm{x}}$ & $14.80 \pm 0.88^{\mathrm{b} / \mathrm{y}}$ & $15.01 \pm 0.57^{\mathrm{a} / \mathrm{y}}$ \\
\hline & HR & $18.25 \pm 0.88^{\mathrm{c} / \mathrm{x}}$ & $20.59 \pm 1.64^{c / x y}$ & $21.17 \pm 0.78^{\mathrm{c} / \mathrm{y}}$ & $21.52 \pm 1.48^{\mathrm{b} / \mathrm{y}}$ \\
\hline \multirow{4}{*}{ Whiteness } & $\mathbf{A F}$ & $40.34 \pm 1.93^{a / x y}$ & $39.96 \pm 0.47^{\mathrm{a} / \mathrm{x}}$ & $41.66 \pm 0.62^{\mathrm{a} / \mathrm{y}}$ & $46.54 \pm 1.45^{\mathrm{a} / \mathrm{z}}$ \\
\hline & & $50.57 \pm 1.51^{\mathrm{b} / \mathrm{x}}$ & $46.06 \pm 0.54 \mathrm{~b} / \mathrm{y}$ & $40.52 \pm 1.20^{\mathrm{a} / \mathrm{z}}$ & $44.33 \pm 0.79^{\mathrm{a} / \mathrm{w}}$ \\
\hline & S-Ch & $45.94 \pm 0.48^{\mathrm{c} / \mathrm{x}}$ & $42.61 \pm 1.08^{c / y}$ & $37.83 \pm 0.71^{\mathrm{b} / \mathrm{z}}$ & $37.98 \pm 0.73^{\mathrm{b} / \mathrm{z}}$ \\
\hline & HR & $51.65 \pm 1.04^{\mathrm{b} / x y}$ & $50.15 \pm 0.58^{\mathrm{d} / \mathrm{x}}$ & $52.72 \pm 0.08^{\mathrm{c} / \mathrm{y}}$ & $53.71 \pm 0.73^{\mathrm{c} / \mathrm{z}}$ \\
\hline
\end{tabular}

AF: no additives; S: commercial sulphites; S-Ch: commercial sulphites + chitosan; HR: formulation containing 4-hexylresorcinol $(0.1 \%)$, chelants and acids.

Different letters $(a, b, c .$.$) in the same column indicate significant differences (p \leq 0.05)$ as a function of treatment; different letters $(\mathrm{x}, \mathrm{y}, \mathrm{z} \ldots)$ in the same row indicate significant differences $(\mathrm{p} \leq 0.05)$ as a function of storage time. 
Table 4. Sensory evaluation of Deepwater pink shrimp during chilled storage: a) Yellow-greenish colour, b) Odour and c) Cephalothorax-tail junction.

\begin{tabular}{l|ccccc} 
& \multicolumn{5}{|c}{ Colour of viscera (a) } \\
Lots & 0 days & 3 days & 6 days & 8 days & 10 days \\
\hline AF & $5.0 \pm 0.0$ & $0.3 \pm 0.5$ & $0.2 \pm 0.3$ & $0.4 \pm 0.3$ & $0.0 \pm 0.0$ \\
S & $5.0 \pm 0.0$ & $0.7 \pm 0.7$ & $0.3 \pm 0.4$ & $0.4 \pm 0.5$ & $0.0 \pm 0.0$ \\
S-Ch & $5.0 \pm 0.0$ & $1.0 \pm 0.8$ & $0.4 \pm 0.5$ & $0.3 \pm 0.3$ & $0.0 \pm 0.0$ \\
HR & $5.0 \pm 0.0$ & $3.5 \pm 0.9$ & $1.8 \pm 0.4$ & $1.5 \pm 0.2$ & $1.5 \pm 0.2$ \\
& \multicolumn{5}{|c}{ Odour (b) } \\
\hline AF & $5.0 \pm 0.0$ & $3.6 \pm 0.8$ & $3.1 \pm 0.5$ & $2.5 \pm 0.3$ & $2.5 \pm 0.2$ \\
S & $5.0 \pm 0.0$ & $3.8 \pm 0.7$ & $2.8 \pm 0.9$ & $2.2 \pm 0.8$ & $2.2 \pm 0.6$ \\
S-Ch & $5.0 \pm 0.0$ & $3.7 \pm 0.6$ & $2.9 \pm 0.7$ & $2.7 \pm 0.3$ & $2.5 \pm 0.4$ \\
HR & $5.0 \pm 0.0$ & $4.0 \pm 0.7$ & $3.0 \pm 0.7$ & $2.9 \pm 0.5$ & $2.5 \pm 0.3$ \\
& $5.0 \pm 0.0$ & $4.1 \pm 0.8$ & $4.1 \pm 0.5$ & $1.7 \pm 0.3$ & $1.3 \pm 0.4$ \\
AF & $5.0 \pm 0.0$ & $4.2 \pm 0.7$ & $3.9 \pm 0.9$ & $1.7 \pm 0.8$ & $1.2 \pm 0.5$ \\
S & $5.0 \pm 0.0$ & $4.2 \pm 0.6$ & $4.1 \pm 0.7$ & $2.2 \pm 0.3$ & $1.3 \pm 0.5$ \\
S-Ch & $5.0 \pm 0.0$ & $4.2 \pm 0.7$ & $4.2 \pm 0.7$ & $2.4 \pm 0.5$ & $2.0 \pm 0.8$ \\
HR &
\end{tabular}

AF: no additives; S: commercial sulphites; S-Ch: commercial sulphites + chitosan; HR: formulation containing 4-hexylresorcinol $(0.1 \%)$, chelants and acids. 